\title{
Characterization of Fluorotic Enamel After Microabrasion and Desensitizing Agent
}

\section{Caracterización del esmalte fluorótico después de microabrasión y desensibilizante}

\author{
Zavala-Alonso V. DDS, MSc, PhD1; Roque-Márquez G. DDS, MSc²; \\ Patiño-Marín N. DDS, MSc, PhD³; Silva-Herzog D. DDS, MSc, PhD1 \\ 1. Profesor-Investigador, Doctorado en Ciencias Odontológicas, Facultad de Estomatología, \\ Universidad Autónoma de San Luis Potosí, México. \\ 2. Coordinadora del Doctorado en Ciencias Odontológicas, Facultad de Estomatología, \\ Universidad Autónoma de San Luis Potosí, México. \\ 3. Estudiante del Doctorado en Ciencias Odontológicas, Facultad de Estomatología, \\ Universidad Autónoma de San Luis Potosí, México.
}

Correspondence to: Dra. Verónica Zavala-Alonso - nveroza@hotmail.com

D0l: http://dx.doi.org/10.15517/ijds.v0i0.27998

\section{ABSTRACT}

Introduction. Enamel microabrasion is a procedure used for removing a superficial layer of enamel that has some alteration of color and/or texture caused by dental fluorosis. The purpose of this study was to compare the microhardness and micromorphology of the fluorotic enamel surface after microabrasion with $6.6 \%$ hydrochloric acid and silica or $18 \%$ hydrochloric acid and evaluate the effect of desensitizing agent exposure on the treated enamel. Materials and Methods. Twenty anterior teeth with moderate fluorosis were divided into two groups: 1) Perla-Dent ${ }^{\circledR}$ group and 2) Opalustre ${ }^{\circledR}$ group. Each buccal surface of incisors was sectioned to obtain samples $3 \times 3 \mathrm{~mm}$. The samples were then mounted in acrylic blocks. The enamel surface of the blocks was polished, after the microabrasion materials and desensitizing agent were applied according to the manufacturer's instructions. All samples were analyzed by Vickers microhardness tester and scanning electron microscopy (SEM). Results. Both experimental groups presented a decrease in the microhardness values, with statistically significant differences $(p<0.0001)$ when comparing the baseline and after treatments values. To compare the microhardness values after both microabrasion and desensitizing treatment in the study groups, it was observed that the Perla-Dent $\AA$ group obtained lower values than the Opalescence $®$ group with a statistically significant difference $(0<0.0001)$. The representative images of study groups in SEM showed the enamel surface morphology after Perla-Dent $₫$ treatment more irregular and a very marked relief than that observed in enamel surface morphology after Opalustre ${ }^{\circledR}$ treatment. Conclusion. The surface of the enamel was more affected with Perla-Dent $\AA$ treatment than with Opalustre $®$ treatment and the placement of UltraEz ${ }^{\circledR}$ agent does not recover its baseline microhardness. 


\section{KEYWORDS}

Dental fluorosis; Fluorotic enamel; Microabrasion; Desensitizing agent; Microhardness; Surface morphology.

\section{RESUMEN}

Introducción. La microabrasión del esmalte es un procedimiento usado para remover la capa superficial de esmalte que tiene alguna alteración de color y / 0 textura causada por la fluorosis dental. El objetivo de este estudio fue comparar la microdureza y micromorfología de la superficie del esmalte fluorado después de microabrasión con ácido clorhídrico al 6,6\% y sílice ó $18 \%$ de ácido clorhídrico y evaluar el efecto de la exposición del agente desensibilizante sobre el esmalte tratado. Materiales y métodos. 20 dientes anteriores con fluorosis moderada se dividieron en dos grupos: 1) grupo PerlaDent $\AA$ y 2) grupo Opalustre ${ }^{\circledR}$. La superficie bucal se seccionó para obtener muestras de $3 \times 3 \mathrm{~mm}$. Las muestras se montaron luego en bloques acrílicos. La superficie del esmalte de los bloques fue pulida, y posteriormente los materiales de microabrasión y el agente desensibilizante se aplicaron de acuerdo con las instrucciones del fabricante. Todas las muestras fueron analizadas por medio de microdureza Vickers y Microscopía electrónica de barrido (MEB). Resultados. Ambos grupos experimentales presentaron disminución de los valores de microdureza con diferencias estadísticamente significativas $(p<0.0001)$ al comparar los valores de antes y después de los tratamientos. Al comparar los valores de microdureza después del tratamiento de microabrasión y desensibilizante en los grupos de estudio, se observó que el grupo Perla-Dent $₫$ obtuvo valores más bajos que el grupo Opalustre $®$ con diferencia estadísticamente significativa $(p<0.0001)$. Las imágenes representativas de los grupos de estudio en MEB mostraron la morfología de la superficie del esmalte después del tratamiento con Perla-Dent® más irregular y con un relieve más marcado que el observado en la superficie del esmalte después del tratamiento con Opalustre ${ }^{\circledR}$. Conclusión. La superficie del esmalte se presentó más afectada posterior al tratamiento con Perla-Dent@ que con Opalustre ${ }^{\circledR}$ y la colocación del agente UltraEz $®$ no logró recuperar el grado de microdureza basal.

\section{PALABRAS CLAVE}

Fluorosis dental; Esmalte fluorótico; Microabrasión; Desensibilizante; Microdureza; Morfología de superficie.

\section{INTRODUCTION}

Dental fluorosis (DF) is an alteration on enamel surfaces of tooth caused by chronic ingestion of fluoride during development, leading to enamel with a lower mineral content because of changes on its external structure surface (1-2). Fluorosis causes changes in coloring intensity (from opaque white to yellow-brown) of the tooth surface. It also leads to tissue loss. This discoloration and loss of tissue cause serious aesthetic and psychological problems. Research into treatments revealed that, in mild cases, a hydrogen peroxidebased whitening treatment is effective, whereas the microabrasion method is most effective for more serious cases (3). Enamel microabrasion is a procedure used for removing a superficial layer of enamel that has some alteration of color and/or texture. With the technique, a sub layer of enamel with normal characteristics is exposed. As the enamel wear is minimal, microabrasion is considered a safe and conservative procedure, 
when correctly prescribed (4). Scientific studies on microabrasion have been carried out for several years in order to know its effects on the enamel. McCloskey first introduced this technique using $18 \%$ hydrochloric acid to remove superficial tooth structure in teeth affected by fluorosis (5). Later, Croll and Cavanaugh recommended a technique in which a paste composed of hydrochloric acid $(\mathrm{HCl})$ in combination with pumice was applied to the affected area (6). This technique was further modified by Croll, replacing the pumice paste with silicon carbide particles and reducing the concentration of $\mathrm{HCl}$ to $11 \%$, then the concentration was again changed to $6.6 \%(7)$.

The effects of microabrasion on the enamel are related to the compounds, both erosive and abrasive, and the mechanical pressure exerted when using microabrasion cups in slow-speed hand pieces. The common effects include, a significant decrease microhardness values after microabrasion and a significant increase after remineralization with fluoride solutions (8-9), and in relation to the morphology, microscopic evaluations have shown alterations on the enamel surface to include exposure of the interprismatic spaces (10). Most of these investigations have analyzed the effects of various hydrochloric acids with silica compounds; there is very little information on the enamel effects of McCloskey's original formula. Today some authors confirm that this formula is toxic and erosive (4), however, several companies continue to manufacture and offer the formula with great success mainly because of its good results in the elimination of stains and its low cost. Thus, the purpose of this study was to compare the microhardness and micromorphology of the fluorotic enamel surface after microabrasion with $6.6 \%$ hydrochloric acid and silica and 18\% hydrochloric acid and evaluate the effect of desensitizing agent exposure on the abrasioned enamel.

\section{MATERIALS AND METHODS}

Female or male patients between 30 and 50 years of age undergoing extraction of incisors due to periodontal disease at hospital and private clinics of Villa de Reyes (San Luis Potosí, México) which has a water fluoride level between 0.7 and $2 \mathrm{ppm}$, were asked to donate their teeth, and then informed patient consent was obtained. Autonomous University of San Luis Potosi Ethics Committee approved the research project grant CEIFE-025-016. All collected samples were cleaned and disinfected in an ultrasonic bath, then washed in running water, dried and analyzed by visual observation for fluorosis severity according to the Dean Index. A total of 20 anterior teeth (10 central incisors and 10 lateral incisors) with moderate fluorosis, cavity-free and without fractures were included and divided into two groups: 1) Perla-Dent ${ }^{\circledR}$ group (PERLADENT S. de R.L. de C.V., Tijuana,BC, MX) and 2) Opalustre ${ }^{\circledR}$ group (Ultradent Products, South Jordan, UT,USA). Table 1 shows the composition of the materials used in the study. All incisors were stored in distilled water until experimental procedures were performed. Each buccal surface of incisors was sectioned perpendicular to the long axis of the tooth by means of a water-cooled low-speed diamond saw (\#7910, medium size graine; Brasseler, Savannah, GA, USA) to obtain samples $3 \mathrm{~mm}$ in width. The samples were then mounted in acrylic blocks. The enamel surface of the blocks was flattened under water cooling, using the following: Silicon carbide papers of decreasing granulation (\#80, \#120, and 
\#600), and were polished with rubber cup and prophylaxis paste, followed by ultrasonic cleansing in distilled water.

\section{VICKERS MICROHARDNESS ANALYSIS}

The Vickers Microhardeness tester (HVS1000Z, Sinowon, DongGuan, CHN) was used to determine the Vickers microhardness. The indentations were performed in three stages: before any treatment, after microabrasion treatment and after desensitizing agent. Six indentations were performed with a load of $50 \mathrm{Kgf}$ for 30 seconds and a separation of approximately $100 \mu \mathrm{m}$.

In group 1, Perla-Dent $\circledast$ treatment was placed 5 minutes on the surface and without removal, was reapplied 6 times with a total time of 30 minutes, while for the group 2, Opalustre $\circledast$ agent was applied $1 \mathrm{~mm}$ thick and with prophylaxis rubber at low velocity (500 rpm) pressure was applied for 60 seconds, the agent was removed, rinsed and the process repeated 6 times.

Each sample was stored 24 hours in artificial saliva (Viarden, CDMX, MX) at $37^{\circ} \mathrm{C}$ and the desensitizing agent UltraEz $\circledast$ (Ultradent Products, South Jordan, UT,USA) was applied according to the manufacturer's instructions by means of an individualized tray for 60 minutes, the samples were rinsed and dried and a third measurement of the microhardness of the sample was performed.

\section{SCANNING ELECTRON MICROSCOPY ANALYSIS (SEM)}

Representative samples of each phase of application (before, after each treatment and after the desensitizing agent) with each of the microabrasion agents used, were observed with the help of the SEM (JSM-6510, JEOL, Tokyo, JAP) to obtain images of areas of relevance at $80 x$, and at $200 \mu \mathrm{m}$ scale.

\section{STATISTICAL ANALYSIS}

Statistical analysis was performed with GraphPad Prism software version 7.0 (GraphPad Software, Inc. La Jolla, CA, USA). One-way repeated measures ANOVA was used to compare the surface microhardness values at before, after microabrasion and after desensiziting with significance set at $p<0.05$. The post-hoc Tukey's test was used to find significant differences between the means when ANOVA result was significant.

\section{RESULTS}

The mean enamel surface microhardness in Vickers hardness number (VHN) baseline and after microabrasion and desensiziting treatments are shown in Table 2 and Figure 1. The microhardness value at baseline was slightly higher in the Opalustre ${ }^{\circledR}$ group; however the difference was not statistically significant $(p=0.5152)$, showing that the samples used were homogeneous for both groups. Both experimental groups presented a decrease in the microhardness values, with statistically significant differences when comparing the baseline and after treatments values $(p<0.0001)$. After the desensitizing agent was placed in both experimental groups, the microhardness increase its value, with a slightly higher trend in the Perla-Dent $\circledast$ group, however, the difference was not statistically significant $(p>0.05)$. When compare the microhardness values after both microabrasion and desensitizing treatment in the study groups, we can observe that the Perla-Dent $\AA$ group obtained lower values than the Opalescence $®$ group with a statistically significant difference $(p<0.0001)$.

Figures 2 and 3 show representative SEM images of study groups in the different treatment phases. In both groups, the surface morphology of the enamel prior to the microabrasion treatment 
is observed to be irregular with the presence of craters and cracks, also Hunter-Schreger bands can be observed (Fig. 2a and 3a); however, once the microabrasion treatments were applied, the characteristics of the enamel surface changes. The enamel surface where the Perla-Dent $\AA$ treatment was applied, irregular areas and relief were observed as well as conditioning pattern with evidence of the prism core (type I) in some areas was found (Fig. 2b). After the desensitizing treatment was placed, the characteristics of the enamel were observed similar to the microabrasion treatment, even the zones with evidence of the prism core (type I) were still observed (Fig. 2c). The enamel surface where the Opalustre $\circledR$ treatment was applied, it was observed with a more regular relief, the presence of the Hunter-Schreger bands was observed as well as conditioning patterns type I (Fig. 3b). After the desensitizing treatment was placed, surface is observed with the presence of cracks, pores and some Hunter-Schreger bands (Fig. 3c).

Table 1. Composition of the materials used in the study.

\begin{tabular}{|c|c|}
\hline Tradename & Composition \\
\hline Perla-Dent@ PERLADENT & $\mathrm{HCl} 18 \%$ \\
\hline Opalustre $\circledast$, Ultradent & $\mathrm{HCl} 6.6 \%$ and microparticles of silicon carbide in a water-soluble paste \\
\hline ULtraEz®, Ultradent & $3 \%$ potassium nitrate gel with $25 \%$ sodium fluoride \\
\hline Artificial saliva, Viarden® & Sodium, potassium, calcium, magnesium, fluorine, chlorine and phosphate. \\
\hline
\end{tabular}

Table 2. Mean enamel surface microhardness in Vickers Hardness number (VHN) baseline and after microabrasion and desensitizing treatments $(\mathrm{N}=60)$.

\begin{tabular}{cccc}
\hline Group & Baseline & $\begin{array}{c}\text { After Microabrasion } \\
\text { treatment }\end{array}$ & $\begin{array}{c}\text { After Desensitizing } \\
\text { treatment }\end{array}$ \\
\hline Perla-Dent $\circledast$ & $313.8 \pm 33.36^{\mathrm{aA}}$ & $91.29 \pm 31.58^{\mathrm{aB}}$ & $101.4 \pm 33.15^{\mathrm{aB}}$ \\
Opalustre $\AA$ & $324.1 \pm 65.2^{\mathrm{aA}}$ & $160 \pm 73.87 \mathrm{bB}$ & $168.7 \pm 72.47^{\mathrm{bB}}$ \\
\hline
\end{tabular}

Different upper-case letters represent statistical significance within the row, different lower-case letters show statistical difference in the column.

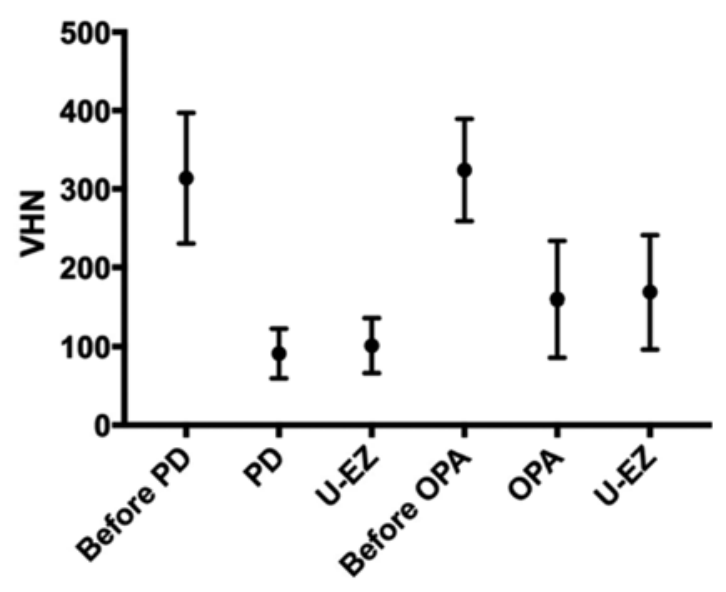

Figure 1. Change in the enamel surface microhardness in Vickers hardness number (VHN) before and after treatments. 

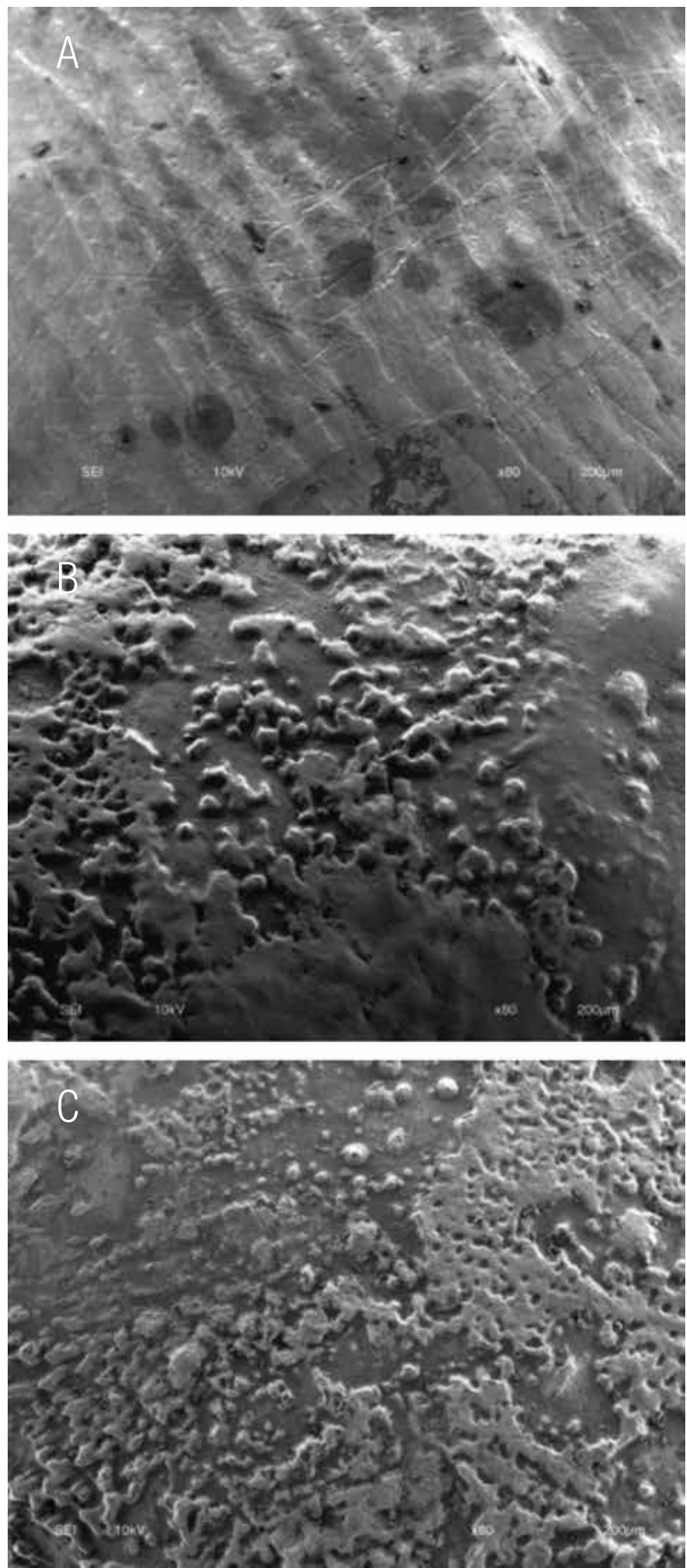

Figure 2. SEM images at $x 80$ of enamel surface treated with Perla-Dent ${ }^{\circledR}$ (A) before treatment; (B) after treatment; and (C) after treatment with desensitizing agent. 

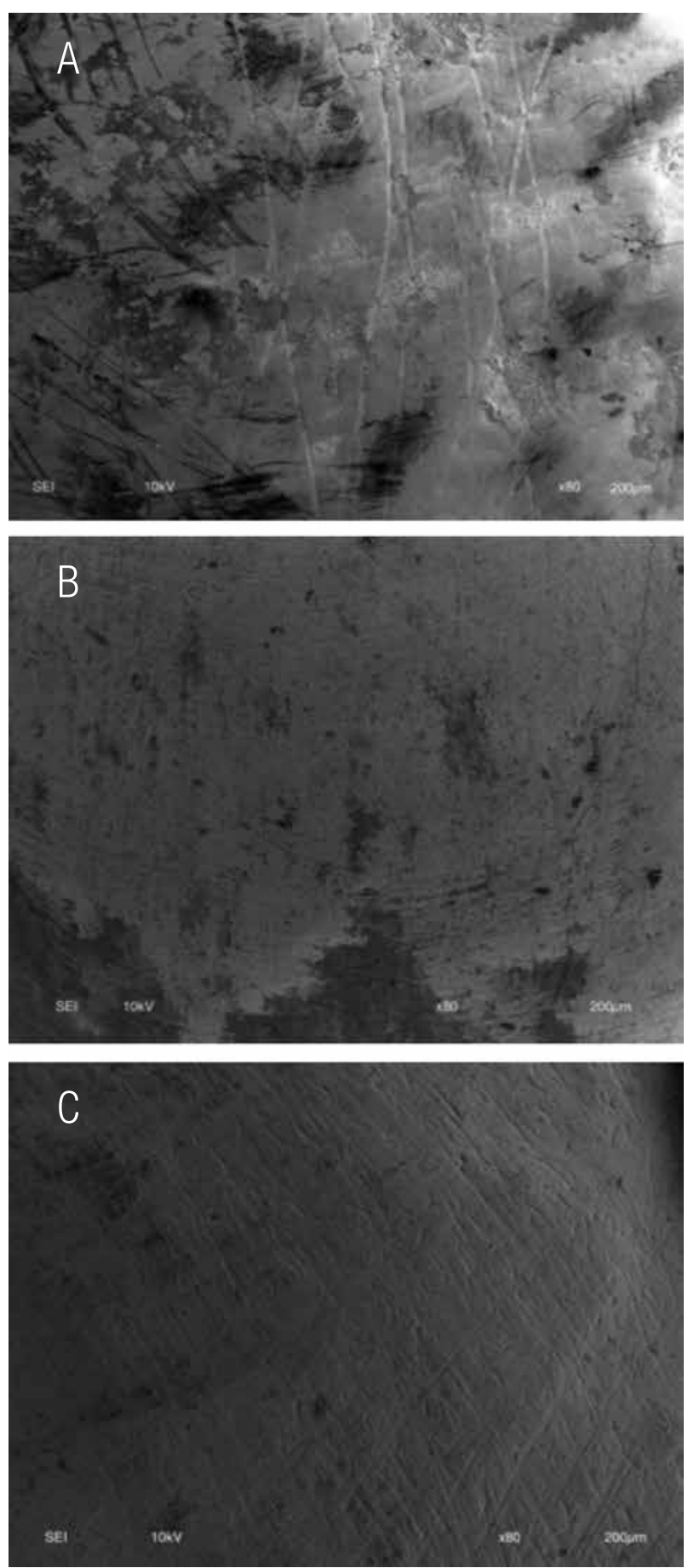

Figure 3: SEM images at $x 80$ of enamel surface treated with Opalustre ${ }^{\circledR}$ (A) before treatment; (B) after treatment; and (C) after treatment with desensitizing agent. 
DISCUSSION

Currently the microabrasion of the enamel has been accepted because it is considered a conservative and non-restorative technique that improves the appearance of the teeth that present alteration of color and defects in its surface. There are mainly two different types of techniques for performing microabrasion; the chemical technique based on $18 \% \mathrm{HCl}$, which was the first proposal and is still being manufactured and is used by a large number of specialists because of its low cost and to the satisfactory clinical results in the removal of superficial enamel stains, although some authors discuss their high toxicity (4-5). The second technique of microabrasion is the chemical-mechanical, which has undergone several modifications, using different types and concentrations of acids, although the most used today is based on 6\% hydrochloric acid and associated with particles of silicon carbide, finding different products with this formulation (11-12). Several authors have proposed polishing with fluoride prophylactic pastes or applying topical fluoride with the aim of enhance the remineralization of microabrasion treated areas (13). In the present study we analyzed and compared the effects on the microhardness and surface morphology of the enamel after using two microabrasion techniques as well as the subsequent application of a desensitizing agent. The mean VHN of samples at baseline was $313.8 \pm 83.36$ and $324.1 \pm 65.2$ for both study groups, which were slightly lower than previously reported 9,14 , this is probably due to the fact that in the present study fluorotic enamel was used and in the previous reports a normal enamel was reported (14). To our knowledge, it is the first time to evaluate the morphological and microhardness of the surface of the enamel with moderate fluorosis after the application of different microabrasion techniques and a desensitizing agent. Most of the published works of this type have evaluated bovine teeth or human teeth free of fluorosis $(3-4,9)$.
According to the results obtained, both enamel microabrasion with $6.6 \% \mathrm{HCL}$ and nanoparticles of silicon carbide and $18 \% \mathrm{HCL}$ solution caused a reduction in microhardness immediately after treatment. However the microhardness obtained with the Perla-Dent $\AA$ group was much lower than that of the Opalustre $\circledast$ group $(p<0.0001)$. This finding is in accordance with that of other studies $(9,13,15-16)$. Parameters such as the type and amount of acid used, its concentration and $\mathrm{pH}$, abrasive medium, time of instrumentation and the application force can affect the amount of enamel erosion during microabrasion treatment (16). In this study PerlaDent ${ }^{\circledR}$ was applied for 30 minutes in 5-minute lapses, without any mechanical pressure, direct contact of a strong acid with a high concentration on the enamel surface was probably what caused the great decrease in microhardness. This finding agrees with that reported by Ahmadi Zenouz et al (9) which reported a much lower microhardness when applying a solution by pressing the surface of the enamel. It has been shown that increased pressure results in higher substance loss. Utilizing a load cell could have distributed the load equally between the samples (17). In their study, Meireles et al (15) report that microabrasion with $\mathrm{HCl}$ significantly removed the superficial enamel layer and caused a larger total demineralization area. The results of microhardness match those found in the SEM since the images after the placement of each of the microabrasion techniques were very different. Perla-Dent $\circledast$ showed irregular surface, exhibited areas with a selective conditioning etching and others with a non-selective pattern, these results agree with those found in Meireles's study (15). In our study we decided to place a desensitizing agent (UltraEZ $®$ ) after the application of microabrasion techniques with the aim of promoting remineralization and consequently the decreased microhardness. UltraEZ $®$ is a unique, sticky and viscous gel with sustained release, 3\% potassium nitrate and $0.25 \%$ sodium fluoride. Its main indications are for sensitive teeth, sealing dentinal tubules of exposed dentin and other areas 
where post-operative sensitivity is a concern, as well as treating sensitivity following bleaching procedure or microabrasion techniques. The results of microhardness after application of the desensitizing agent in both study groups showed a recovery of the VHN value, however the value continued very low with respect to the basal value. Our results are consistent with the findings of many studies demonstrating remineralization effect of fluoride, after erosive procedures (18-20). The morphological characteristics of the surface treated with the desensitizing agent observed with SEM, were similar to the characteristics found after the application of the microabrasion treatment of both study groups, with these results it can be assumed that although the desensitizing agent increases the fluorotic enamel surface microhardness, fails to change its morphological characteristics.

\section{CONCLUSION}

Within the limits of the present investigation (in vitro study, age range), it can be concluded that although the two techniques of microabrasion evaluated (chemical and chemical-mechanical techniques) affect the fluorotic enamel surface microhardness, the chemical microabrasion

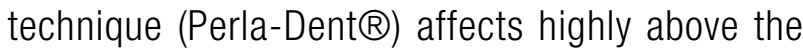
chemical-mechanical microabrasion technique (Opalustre $®$ ) and the placement of a desensitizing agent based on sodium fluoride, although it increases the microhardness after the application of microabrasion techniques, it does not recover its baseline microhardness.

\section{ACKNOWLEDGMENTS}

This work was partially supported by Consejo Nacional de Ciencia y Tecnología (CONACYT grant CB-178261) and PERLADENT® Company.

\section{REFERENCES}

1. Fejerskov O., Larsen M., Baelum V. Dental tissue effects of fluoride. Adv Dent Res. 1994; 8 (1):15-31.

2. Silva-Benítez E., Zavala-Alonso V., MartinezCastanon G., Loyola-Rodriguez J., PatiñoMarin N., Ortega-Pedrajo I., and GarcíaGodoy F. Shear bond strength evaluation of bonded molar tubes on fluorotic molars. Angle Orthod. 2013; 83 (1): 152-57.

3. Bağlar S., Çolak H., Hamidi M. Evaluation of Novel Microabrasion Paste as a Dental Bleaching Material and Effects on Enamel Surface. J Esthet Restor Dent. 2015; 27 (5): 258-66.

4. Pini N. I., Costa R., Bertoldo C. E., Aguiar F. H., Lovadino J. R., Lima D. A. Enamel morphology after microabrasion with experimental compounds. Contemp Clin Dent. 2015; 6 (2): 170-75.

5. McCloskey R. J. A Technique for removal of fluorosis stains. J. Am Dent Assoc.1984; 109 (1): 63-64.

6. Croll T. P., Cavanaugh R. R. Enamel color modification by controlled hydrochloric acid pumice abrasion. I. technique and examples. Quintessence Int. 1986;17 (2): 81-87.

7. Croll T. P. Enamel microabrasion for removal of superficial dysmineralization and decalcification defects. J Am Dent Assoc. 1990; 120 (4): 411-15.

8. Fragoso L. S., Lima D. A., de Alexandre R. S., Bertoldo C. E., Aguiar F. H., Lovadino J. R. Evaluation of physical properties of enamel after microabrasion, polishing, and storage in artificial saliva. Biomed Mater. 2011; 6 (3): 035001.

9. Ahmadi G., Ezoji F., Enderami S., Khafri S. Effect of Fluoride, Casein PhosphopeptideAmorphous Calcium Phosphate and Casein 
Phosphopeptide-Amorphous CalciumPhosphate Fluoride on Enamel Surface Microhardness After Microabrasion: An in Vitro Study. J Dent (Tehran). 2015; 12 (10): 705-11.

10. Tong L. S., Pang M. K., Mok N. Y., King N. M., Wei S. H. The effects of etching, micro-abrasion, and bleaching on surface enamel. J Dent Res 1993; 72 (1): 67-71.

11. Croll T.P.Combiningresincompositebonding and enamel microabrasion. Quintessence Int 1996; 27 (10): 669-71.

12. Bertoldo C., Lima D., Fragoso L., Ambrosano G., Aguiar F., Lovadino J. Evaluation of the effect of different methods of microabrasion and polishing on surface roughness of dental enamel. Indian J Dent Res. 2014; 25 (3): 290-93.

13. Ulukapi H. Effect of different bleaching techniques on enamel surface microhardness. Quintessence Int. 2007; 38 (4): 201-5.

14. Lata S., Varghese N. O., Varughese J. M. Remineralization potential of fluoride and amorphous calcium phosphate-casein phospho peptide on enamel lesions: An in vitro comparative evaluation. J Conserv Dent. 2010; 13 (1): 42-46.

15. Meireles S. S., Andre Dde A., Leida F. L., Bocangel J. S., Demarco F. F. Surface roughness and enamel loss with two microabrasion techniques. J Contemp Dent Pract. 2009;10 (1): 58-65.

16. Paic M., Sener B., Schug J., Schmidlin P. R. Effects of microabrasion on substance loss, surface roughness, and colorimetric changes on enamel in vitro. Quintessence Int. 2008; 39 (6): 517-22.

17. Dalzell D. P., Howes R. I., Hubler P. M. Microabrasion: effect of time, number of applications, and pressure on enameloss. Pediatr Dent. 1995; 17 (3): 207-11.

18. Carvalho F. G., Brasil V. L., Silva Filho T. J., Carlo H. L., Santos R. L., Lima B. A. Protective effect of calcium nanophosphate and CPP-ACP agents on enamel erosion. Braz Oral Res. 2013; 27 (6): 463-70.

19. Tantbirojn D., Huang A., Ericson M. D., Poolthong S. Change in surface hardness of enamel by a cola drink and a CPP-ACP paste. J Dent. 2008; 36 (1): 74-79.

20. Jayarajan J., Janardhanam P., Jayakumar P., Deepika C. Efficacy of CPP-ACP and CPP$\mathrm{ACPF}$ on enamel remineralization - an in vitro study using scanning electron microscope and DIAGNOdent. Indian J Dent Res. 2011; 22 (1): 77-82.

21. Rirattanapong P., Vongsavan K., Tepvichaisillapakul M. Effect of five different dental products on surface hardness of enamel exposed to chlorinated water in vitro. Southeast Asian J Trop Med Public Health. 2011; 42 (5): 1293-98.

22. Madhavan S., Nayak M., Shenoy A., Shetty R., Prasad K. Dentinal hypersensitivity: A comparative clinical evaluation of CPP-ACP $\mathrm{F}$, sodium fluoride, propolis, and placebo. $\mathrm{J}$ Conserv Dent. 2012;15 (4): 315-18. 